SVU- International Journal of Veterinary Sciences, 4(1): 19-24, 2021.

Print ISSN: 2535-1826

Online ISSN: 2535-1877

CrossMark

Research Article

Open Access

\title{
Camel Abortion Status in Iran- A Mini Review
}

\section{Masoud Hassani*}

*Faculty of Veterinary Medicine, University of Tehran, Tehran, Iran Veterinary Council, Hamedan, Iran

\section{Abstract}

About 180,000 old world camels (OWCs) including one-humped (Camelus Dromedarius) and two-humped (Camelus Bactrianus) camels (only 100-300 individuals) live in Iran. Abortion is one of the problems of camel breeders in Iran at various aspects, i.e. economical, animal healthcare or zoonotic. So far, some epizootological studies have been conducted on infectious diseases of Iranian camels. However, there is the absence of comprehensive information on the camel abortion status in Iran. We aimed at collecting all the available information on abortion in Dromedary and Bactrian camels in Iran to have a better picture of the situation in the country. Based on studies that examined the causes of abortion of dromedary camels in different provinces; Brucellosis, trypanosomiasis, leptospirosis, salmonellosis, bovine viral diarrhea, infectious bovine rhinotracheitis and aspergillosis are common factors of abortion in the country. This review can provide baseline information for future research and give significant contributions to figuring the disease control strategies.

Keywords: Abortion, Dromedary camel, Bactrian camel, Iran.

DOI: 10.21608/svu.2021.46492.1086 Received: October 15, 2020 Accepted: January 27, 2021 Published: February 11, 2021 Corresponding Author: Masoud Hassani E-mail: Masoud.Hassani@ut.ac.ir. Citation: Hassani, 2021. Camel Abortion Status in Iran- A Mini Review. SVU-IJVS 2021, 4(1): 19-24. Copyright: (C Hassani. This is an open access article distributed under the terms of the creative common attribution license, which permits unrestricted use, distribution and reproduction in any medium provided the original author and source are created.

Competing interest: The authors have declared that no competing interest exists.

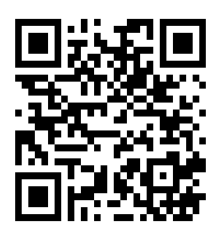




\section{INTRODUCTION}

Abortion is defined when the mother animal expels the fetus before it is due at any time during pregnancy. The diagnosis of abortions is challenge to the farmers and veterinarians and may be missed in the early stages, since there is little to be seen. The main signs of abortion include a placenta protruding from the vulva, presence of a dead fetus in a paddock or pen, or indications of receptivity to a male (Fowler, 2011). knowledge on the incidence and etiology of abortion in camelids are limited and various infectious, traumatic or toxic factors have been associated with abortion in camels (Tibary et al. 2006). Abortion can cause huge economic losses to camel breading industry including frank abortion losses, uterine infections, reduce productive rate, increased camel calving interval and infertility, veterinary cost, reduce milk production and culling or death of animals. In addition to this the cost of human disease given that many of the agents of abortion are zoonotic (Hassani et al. 2019; Hassani and Hamedi, 2019).

Iran is home to two species of OldWorld Camels (OWCs): Camelus dromedarius and Camelus bactrianus. The populations of Dromedary and Bactrian camels are estimated to be approximately 180,000 and 100-300, respectively. Camel husbandry is a common practice in deserts of Iran in a traditional way for its milk, meat, wool and also as work power in agriculture and a pack animal in transportation (Iranian Ministry of Agriculture, 2018). So far, some epizootological studies have been conducted on infectious diseases of Iranian camels. However, there is the absence of comprehensive information on the camel abortion status in Iran. We aimed at collecting all the available information on abortion in Dromedary and Bactrian camels in Iran to have a better picture of the situation in the country.

CAMEL ABORTION STATUS IN IRAN

There is little information about the abortion in Dromedaries and none about Bactrian camels in Iran. In 2014, The outbreak of abortion storm in camel herds have been documented in Qom province, where 494 pregnant camels from total of $846(58.4 \%)$ and 35 herds from $45(77.8 \%)$ was aborted. The rate of abortion in herds was from 14 to $100 \%$ (Barani et al. 2017). In Iranian dromedary camels, reported infectious causes of abortion include brucellosis, trypanosomiasis, leptospirosis, salmonellosis, bovine viral diarrhea, infectious bovine rhinotracheitis and aspergillosis (Table 1).

Based on the serological tests, camels are highly susceptible to Brucella spp., with the prevalence up to $12.6 \%$ but so far clinical signs haven't been documented (Hassani and Nayeri Fasaei, 2019). Some researchers (Dehkordi \& Taghizadeh, 2012 and Dehkordi et al. 2012) believe that brucellosis may act as an important causative agent of abortion in camels, as Brucella spp. DNA (B. abortus and B. melitensis) was isolated in $11.4 \%$ and $32.5 \%$ of aborted fetuses in different regions of Iran.

Prevalence rates between 0 and $19.5 \%$ for Trypanosoma infections have been reported in dromedary camels of Iran (Sazmand and Joachim, 2017). Abortion associated with outbreaks of trypanosomiasis have been documented in dromedary herds of Iran; however, there is only one report on the role of $T$. evansi infection in camel abortion (Zakian et al, 2016; Mirshekar et al, 2017). Nazem et al. (2020) examined 244 
abomasal contents of aborted fetuses were collected from eastern provinces and showed that $41(16.8 \%)$ aborted fetuses
Mosleh (2017) examined 10 gallbladder content and amniotic fluid of aborted fetuses from dromedaries in Khorasan

Table 1. Infectious causes of abortion in Dromedary camel fetal samples in Iran

\begin{tabular}{|c|c|c|c|c|c|}
\hline Pathogen & Study area & Sample type & $\begin{array}{l}\text { No. of } \\
\text { sample }\end{array}$ & Method(s): No. of positive (\%) & Reference \\
\hline \multirow[t]{2}{*}{ Brucella spp. } & Isfahan & $\begin{array}{c}\text { Abomasal } \\
\text { contents }\end{array}$ & 35 & $\begin{array}{l}\text { Bacterial culture: } 4 \text { (11.4) } \\
\text { Multiplex PCR: } 4 \text { (11.4) }\end{array}$ & $\begin{array}{l}\text { Dehkordi \& } \\
\text { Taghizadeh (2 }\end{array}$ \\
\hline & $\begin{array}{l}\text { Different } \\
\text { regions }\end{array}$ & $\begin{array}{c}\text { Abomasal } \\
\text { contents }\end{array}$ & 618 & Conventional PCR: 201 (32.5) & Dehkordi et al \\
\hline $\begin{array}{c}\text { Ttypanosoma } \\
\text { evunsi }\end{array}$ & $\begin{array}{c}\text { Different } \\
\text { regions }\end{array}$ & $\begin{array}{c}\text { Abomasal } \\
\text { contents }\end{array}$ & 244 & PCR: 41(16.8) & Nazem et al. \\
\hline $\begin{array}{l}\text { Leptospira } \\
\text { interrogans }\end{array}$ & Isfahan & $\begin{array}{l}\text { Abomasal } \\
\text { contents }\end{array}$ & 35 & $\begin{array}{l}\text { Bacterial culture: } 7 \text { (20) } \\
\text { Multiplex PCR: } 8 \text { (22.8) }\end{array}$ & $\begin{array}{l}\text { Dehkordi \& } \\
\text { Taghizadeh (2 }\end{array}$ \\
\hline Salmonella spp. & $\begin{array}{c}\text { Khorasan } \\
\text { Razavi }\end{array}$ & $\begin{array}{l}\text { Gallbladder } \\
\text { content, amniotic } \\
\text { fluid }\end{array}$ & 10 & Bacterial culture: 2 (20) & $\begin{array}{l}\text { Muhammadi \& } \\
\text { Mosleh, (2017 }\end{array}$ \\
\hline $\begin{array}{c}\text { Bovine viral } \\
\text { diarrhea virus }\end{array}$ & $\begin{array}{c}\text { Different } \\
\text { regions }\end{array}$ & $\begin{array}{l}\text { Abomasal } \\
\text { contents }\end{array}$ & 214 & $\begin{array}{l}\text { Antigen capture ELISA: } 27 \\
\qquad(12.6) \\
\text { Real-Time PCR: } 32 \text { (14.9) }\end{array}$ & Dehkordi, $(20$ \\
\hline $\begin{array}{l}\text { Bovine herpes } \\
\text { virus type } 1\end{array}$ & $\begin{array}{c}\text { Different } \\
\text { regions }\end{array}$ & $\begin{array}{c}\text { Abomasal } \\
\text { contents }\end{array}$ & 79 & $\begin{array}{l}\text { Conventional PCR: } 8 \text { (10.1) } \\
\text { Real-Time PCR: } 10 \text { (12.6) }\end{array}$ & $\begin{array}{l}\text { Dehkordi et al } \\
\text { (2013) }\end{array}$ \\
\hline Aspergillus spp. & $\begin{array}{c}\text { Different } \\
\text { regions }\end{array}$ & $\begin{array}{l}\text { Abomasal } \\
\text { contents }\end{array}$ & 161 & Real-Time PCR: 19 (11.8) & $\begin{array}{l}\text { Dehkordi et al } \\
\text { (2012) }\end{array}$ \\
\hline
\end{tabular}

were infected with $T$. evansi.

Rafiei and Maghami (1959) detected anti- Leptospira icterohemorrhagiae antibodies in a female camel, which suffered from hematuria that later led to abortion. Infection to Leptospira was reported in range 2 to $27.9 \%$ in dromedaries from different parts of Iran (Hassani and Nayeri Fasaei, 2020). In a bacterial culture and PCR survey, Leptospira as an agent of abortion in camels, detected from $20-22.8 \%$ of aborted fetuses in Iran (Dehkordi and Taghizadeh, 2012).

In the only report on Salmonella outbreak in camels in Iran, Muhammadi and
Razavi and isolated the pathogen from 2 cases.

In 2010, a study on camel sera from Tehran province by serum neutralization test (SNT), showed that bovine viral diarrhea virus (BVDV) was prevalent (27/137) in camels of the region (Raoofi et al. 2010). Afterwards, Dehkordi (2011) revealed $27(12.6 \%)$ and $32(14.9 \%)$ of 214 aborted camel fetuses from some parts of Iran are BVDV positive using antigen capture ELISA and Real-Time PCR respectively.

So far antibodies to Bovine Herpes Virus-1 (BoHV-1) causing infectious bovine rhinotracheitis, have been detected range from 0 to $7.3 \%$ in Iranian camels 
(Raoofi et al. 2012; Sazmand et al. 2014; Baghbanian, 2017). In Dehkordi et al (2013) work from parts of Iran, 8 (10.1\%) and $10(12.6 \%)$ of 79 aborted camel fetuses were positive for BoHV-1 based on conventional and real-time PCR respectively.

In the only study on mycotic abortion in camels in Iran, Aspergillus species (A. fumigatus, $A$. flavus, $A$. niger and $A$. terreus) were detected in $11.8 \%$ (19/161) of aborted fetuses (Dehkordi et al. 2012).

Other camel infectious factors causing abortion including Coxiella burnetii, Anaplasma spp. and Bluetongue virus have been documented in Iran but now, we don't know whether they act as a causative agent of abortion in Iranian camels or not (Hassani et al. 2019; Hassani and Hamedi, 2019; Hassani and Madadgar, 2020).

Although occurrence of abortion in the camels of this country has multifactorial etiologies, but the present study could represent infectious diseases as a serious risk factor in predisposing the camels to abortion. The current strategy for control of camel abortion in Iran is voluntary and relies on individual producers to decide if abortion is a significant problem in their own herds and need aggressive control efforts (Hassani et al. 2019; Hassani and Hamedi, 2019). A well-defined control strategy for preventing and controlling infectious abortion in camels of Iran should be based on further epidemiological studies on causes of abortion, control of animal trafficking from neighboring countries, employing good biosecurity practices that inhibit the introduction and spread of infectious causes of abortion in the herd and using vaccination programs.

\section{ABBREVIATIONS}

spp.: species; BVDV: bovine viral diarrhea virus; BoHV-1: Bovine Herpes Virus-1

\section{ACKNOWLEDGEMENTS}

Declared none.

\section{CONFLICT OF INTEREST}

The author declares that he has no conflict of interest.

\section{FUNDING}

The author received no financial support for the research, and/or publication of this article.

\section{REFERENCES}

Baghbanian, H., 2017. Seroprevalence of Bovine Viral Diarrhea Virus, Infecious Bovine Rhinotracheitis Virus (Bovine Herpes Virus - 1) and Bovine Ephemeral Fever in Khuzestan camels, DVM thesis, Veterinary School of Shahid Chamran University, Iran.

Barani S, Salar Amoli J, Moghadas E, Ahmadi A, Tohidi H, Hasanzadeh R (2017). Abortion storm in camel herds in central region of Iran (Qom province). Applied Animal Science Research Journal, 6 (23): 11-16. https://doi.org/10.22092/aasrj.2017.1 15779.

Dehkordi FS (2011). Prevalence study of Bovine viral diarrhea virus by evaluation of antigen capture ELISA and RT-PCR assay in Bovine, Ovine, Caprine, Buffalo and Camel aborted fetuses in Iran. AMB Express, 1(1): 16. https://doi.org/10.1186/2191-0855$1-32$

Dehkordi FS, Haghighi N, Momtaz H, Salari RafsanjaniM, Momeni M 
(2013). Conventional vs real-time PCR for detection of bovine herpes virus type 1 in aborted bovine, buffalo and camel fetuses. Bulgarian Journal of Veterinary Medicine, 16(2): 102111.

Dehkordi FS, Momtaz H, Doosti A (2012). Application of Real-Time PCR for detection of Aspergillus species in aborted ruminant foetuses. Bulgarian Journal of Veterinary Medicine, 15(1): 30-36.

Dehkordi FS, Saberian S, Momtaz H (2012). Detection and segregation of Brucella abortus and Brucella melitensis in aborted bovine, ovine, caprine, buffaloes and camelid fetuses by application of conventional and real-time polymerase chain reaction. The Thai Journal of Veterinary Medicine, 42(1): 13-20.

Dehkordi FS, Taghizadeh F (2012). Prevalence and some risk factors associated with brucellosis and leptospirosis in aborted fetuses of ruminant species. Research Opinions in Animal and Veterinary Sciences, 2(4): 275-281.

Fowler, M.E., 2011. Medicine and surgery of camelids 3 rd ed. Wiley-Blackwell.

Hassani M, Nayeri Fasaei B (2020). A Meta-Analysis of the Prevalence of Leptospirosis and its Serovars in Livestock Population of Iran. Journal of Veterinary Research, 75(3): 262270.

https://doi.org/10.22059/jvr.2019.257 138.2792

Hassani, M., Esmaeili, H., Hamedi, M., 2019. Infectious diseases of camel in Iran (first part: bacterial diseases) .In: 5th National Animal Health Management Seminars. 20 February. Shiraz, Iran. pp. 199-204.

Hassani, M., Hamedi, M., 2019. Infectious diseases of camel in Iran (second part: viral diseases). In: 5th National Animal Health Management Seminars. 20 February. Shiraz, Iran. pp. 205-209.

Hassani, M., Madadgar, O., 2020. What do we know about non-pathogenic viral infections of camel in IRAN? In: International camelid symposium. 2226 June. Luawms, Uthal, Pakistan. p. 24.

Hassani, M., Nayeri Fasai, B., 2019. Camel Brucellosis in Iran. In: The 4th International \& the 8th National Iranian Congress of Brucellosis. 1314 November. Tehran, Iran. p. 14.

Iranian Ministry of Agriculture (2018). Annual production report. Tehran, Iran: Department of Animal Production, Agriculture-Jahad Ministry of Iran.

Mirshekar F, Yakhchali M, Shariati-Sharifi F (2017). Trypanosoma evansi infection and major risk factors for Iranian one-humped camels (Camelus dromedarius). Journal of Parasitic Diseases, $\quad 41(3)$ : $\quad 854-858$. https://doi.org/10.1007/s12639-0170905-7

Mohammadi G, Najafi S (2017). Salmonellosis outbreak in a herd of camel. Applied Animal Science Research Journal, 6(23): 7-10. https://doi.org/10.22092/aasrj.2017.1 15778

Nazem M, Karimidehkordi M, Moghadam M F (2020). Detection of 
Trypanosoma evansi in camel abortions (Camelus dromedarius) in Iran using polymerase chain reaction. Turkish Journal of Veterinary and Animal Sciences, 44(2): 358-363. https://doi.org/10.3906/vet-1908-76

Rafiei A, Maghami G (1959). Sur la frequence de leptospirose en Iran. Archives of Razi Institute, 12(1), 63$\underline{68 .}$ https://doi.org/10.22092/ari.1960.108 $\underline{432}$

Raoofi A, Hemmatzadeh F, Ghanaei AM (2010). Serological survey of antibodies against BVD virus in camels (Camelus dromedarius) in Iran. Tropical Animal Health and Production, 42(3): 411-4. https://doi.org/10.1007/s11250-0099435-3

Raoofi A, Hemmatzedeh F, Ghanaei AM (2012). Serological survey in camels (Camelus dromedaries) to detect antibodies against bovine herpesvirus type-1 and Mycobacterium avium paratuberculosis in Iran. Journal of Camel Practice and Research, 19(1): 65-68.

Sazmand A, Joachim A (2017). Parasitic diseases of camels in Iran (19312017) - a literature review. Parasite, 24(21). https://doi.org/10.1051/parasite/2017 024

Sazmand A, Seyfi Abad Shapouri MR, Hekmatimoghaddam S (2014). A Seroepizootological Study on Bovine Herpesvirus 1 (BoHV-1) Infection in Camels (Camelus dromedarius) in Yazd Province. Journal of Veterinary Microbiology, 10 (1): 9-16.
Tibary A, Fite C, Anouassi A, Sghiri A (2006). Infectious causes of reproductive loss in camelids. Theriogenology, 66(3): 633-647. https://doi.org/10.1016/j.theriogenolo gy.2006.04.008

Zakian A, Nouri M, Safaei P, MohammadSadegh M, Kahroba H, Mokhber Dezfouli MR, Moallemian R (2017). An acute outbreak of natural Trypanosoma evansi infection in camel (Camelus dromedarius) herds in the southwestern Iran. Comparative Clinical Pathology, 26(1) :51-59. https://doi.org/10.1007/s00580-0162345-7 